(Житомирський державний університет імені Івана Франка)

\title{
ВІТЧИЗНЯНИЙ ТА ЗАРУБІЖНИЙ ДОСВІД ПРОФЕСІЙНОӤ ПІДГОТОВКИ КЕРІВНИКІВ НАВЧАЛЬНИХ ЗАКЛАДІВ В УМОВАХ МАГІСТРАТУРИ
}

У статті представлено вітчизняний та зарубіжний досвід професійної підготовки керівників навчальних закладів, розглянуто ї̈ форми та методи, розглянуто підготовку керівників у сфері освіти у країнах Північної Америки, Європи, Японії та України, проведено аналіз досліджень і публікацій з даного питання, висвітлено основні характеристики змісту підготовки управлінців сфери освіти.

Ключові слова: керівник, керівник навчального закладу, магістратура, магістерська підготовка, освітні установи, навчальний процес.

Постановка проблеми. Освіта в наш час $є$ основою добробуту як суспільства загалом, так і кожної людини зокрема. Процес підготовки кваліфікованого фахівця є однією з головних проблем професійної педагогіки. У становленні професіонала актуальним завданням сьогодення $\epsilon$ така підготовка, результатом якої виступає здатність легко адаптуватися до змін у житті, удосконалювати власну професійну компетентність, що можна забезпечити за умов використання не лише вітчизняного, а також і зарубіжного досвіду. Набули модернізації функції керівника навчального закладу. До сучасних функцій керівника належать не лише аналіз, планування, організація, мотивація та контроль, а й бачення стратегії та розвитку навчального закладу з урахуванням найкращого світового досвіду, здійснення моніторингу освітнього процесу, управління розвитком та фінансами закладу освіти, управління маркетинговою діяльністю, внутрішня та зовнішня комунікація, здійснення стратегічного управління навчальним закладом, забезпечення саморозвитку науково-педагогічних кадрів та учнів (студентів). Підготовлений до професійної діяльності майбутній фахівець зі сформованим високим рівнем управлінської культури матиме можливість більш гнучко аналізувати різні ситуації, прогнозувати найбільш ефективні шляхи функціонування навчального закладу, керувати закладом, мобільно реагувати на зміни в соціальному, культурному й економічному житті суспільства, здійснювати ефективне ділове спілкування у процесі професійної діяльності, самовдосконалюватися протягом усього життя.

Аналіз основних джерел та наукових публікацій. Питанням підготовки керівників навчальних закладів у самих закладах освіти та у післядипломній освіті займалися такі науковці, як В. Бондар, С. Вершловський, С. Змєєв, Ю. Кулюткін, В. Олійник, Н. Протасова, М. Романенко, Л. Спірін, О. Тонконога та ін.

С. Редько стверджує, що у сучасних суспільних умовах, готуючи керівників навчальних закладів, необхідно використовувати природний потенціал кожної окремої особистості. Автор вважає, що з метою підвищення ефективності підготовки фахівців, майбутніх управлінців, необхідно досліджувати властивості студентів на всіх рівнях структури особистості (психофізіологічному, психічному та соціально-психологічному) та враховувати їх у процесі навчання; спрямовувати професійне навчання студентів на підготовку їх до управлінської діяльності; передбачити використання новітніх педагогічних технологій у навчально-виховному процесі 3 метою розвитку управлінських здібностей студентів; забезпечити закріплення набутих знань та постійний тренінг первинних управлінських навичок [1].

С. Байбородова, вивчаючи досвід підготовки керівних кадрів освіти у Великій Британії, виявила, що керівників навчальних закладів готують у спеціально створених навчальних центрах при університетах, які працюють за єдиним уніфікованим планом. У кожному центрі викладання здійснюється одним консультантом, відповідальним за підготовку директорів у даному регіоні. Навчальна програма побудована на основі Національних стандартів для директорів (National Standards for Headteachers). 3 урахуванням основних сфер керівництва побудована вся програма навчання майбутніх директорів. Викладання ведеться в п’ятьох модулях. Два обов'язкові модулі - стратегічне планування та посадова відповідальність; і від одного до трьох модулів за вибором - освіта та навчання; розвиток і використовування штату й ресурсів; люди та взаємостосунки [2].

Обов'язкові модулі зі стратегічного планування та посадової відповідальності мають на меті навчити директорів розробляти стратегічне бачення розвитку школи, аналізувати і планувати майбутнє, а також вивчення правових основ управління, опанування способами раціональної й ефективної звітності школи перед керівниками освітніх структур, учнями, батьками, колективами місцевих працедавців і місцевим співтовариством.

На думку дослідниці, дана програма 3 погляду реформування системи освіти на сучасному етапі важлива для нашої країни. Багато ідей і інновацій щодо підготовки керівних кадрів у Великій Британії 
було б корисно використовувати при навчанні цих фахівців у педагогічних навчальних закладах [2].

Окреслення невирішених питань. Теоретичний аналіз досліджуваної проблеми дає підстави стверджувати, що на сучасному етапі існує визначена наукова база підготовки менеджерів освіти у вищих педагогічних навчальних закладах. Однак, проблема формування управлінської культури керівників навчальних закладів потребує детального наукового вивчення, тому що на сьогоднішній день закладами здебільшого керують люди, які не мають спеціальної фахової підготовки як управлінці і формування їхньої управлінської культури $є$ і залишається актуальним. Також в умовах реформування вітчизняної системи освіти важливим є запозичення іноземного досвіду підготовки менеджерів освіти. Однак, дане питання розглянуто науковцями не у повній мірі, що і зумовило вивчення зарубіжного та вітчизняного досвіду формування управлінської культури керівників навчальних закладів у професійній підготовці.

Мета та завдання статті - дослідити процес професійної підготовки майбутніх керівників навчальних закладів в Україні та за кордоном.

Виклад основного матеріалу. Необхідність використання у вітчизняній системі вищої освіти найкращого зарубіжного досвіду такої підготовки потребує його детального аналізу. Існують різні моделі підготовки майбутніх керівників навчальних закладів, яка $є$ складовою моделі підготовки керівного складу персоналу в цілому. Американська модель передбачає превентивну підготовку керівника у вищому навчальному закладі до початку кар'єри. Теоретичні знання є основою для майбутньої практичної діяльності. Магістерська підготовка майбутніх керівників навчальних закладів у США враховує низку соціальних, економічних, демографічних та структурних чинників, які змінюють світ, а разом із тим - й очікування від освітніх закладів. Розглянемо цілі підготовки за магістерською програмою "Управління освітою" в США. В американських університетах, таких як Wake Forest University School of Business, Maryville University, Alliant International University та інших підготовка фахівців у сфері управління навчальним закладом здійснюється не лише на теоретичному рівні, а й на практичному. Так, наприклад у Wake Forest University School of Business тривалість навчання в магістратурі складає 10 місяців та базується на знаннях, які отримані на бакалавраті. Програма починається у червні з інтенсивного 6-тижневого модуля, який готує студентів до магістерського бізнескурсу. Осінній та весняний семестри складаються з чотирьох модулів по вивченню основ фінансів, маркетингу, управління, бізнес-аналітики, бухгалтерського обліку, економіки, інформаційних технологій, етики, організаційної поведінки та лідерства. В університеті існує програма практичного навчання (ALP), командні консалтингові проекти, у межах яких студенти працюють з бізнес-спонсорами та клієнтами, допомагають студентам отримати професійні навички.

В університеті Maryville University навчання зорієнтоване на високий рівень освіти та націлене на підготовку ефективних лідерів, виконавців, керівників навчальних закладів, менеджерів та підприємців. Студентів навчають вирішувати реальні робочі завдання у класі та за його межами. Під час навчання студенти вивчають курси у галузі бухгалтерської справи, бізнес-адміністрування, фінансових послуг, інформаційних систем та інших дисциплін.

Alliant International University дає можливість студентам отримати реальний досвід роботи управлінця на регіональному та міжнародному рівнях за рахунок консультування, стажування, професійного розвитку та суспільної роботи. Навчання в магістратурі триває два роки, під час яких вивчається 8 основних курсів та 4 спеціальних. Основні курси розвивають управлінські знання, аналітичний потенціал та культурний вплив. Студенти вивчають дисципліни у галузі підприємництва, інформатики, менеджменту та адміністрування людськими ресурсами, маркетингу, технологій управління, лідерства, психології управління.

Метою навчання за магістерською програмою "Управління освітою" в Північно-західному університеті є навчити студентів: концептуалізувати (осмислювати) вищу освіту на основі збагачених теоретичних знань та активної професійної практики, включаючи розуміння системи вищої освіти, цінностей, політики та практики ¥ї функціонування; розвивати розуміння контексту викладання в професійній практиці, а також складні відносини між різними аспектами цього контексту; розвивати навички дослідження для аналізу проблем, загроз та можливостей, які співіснують у закладах вищої освіти та поза ними, а також навчитися використовувати результати аналізу на користь цілеспрямованої діяльності; розвивати навички залучення до продуктивного діалогу та переговорів із різними зацікавленими сторонами; цінувати важливість продовження навчання відносно професійного життя та оволодіти концептуальною структурою й навичками, які є необхідними для такого навчання.

У результаті навчання за магістерською програмою "Управління освітою" в Північно-західному університеті студент-магістрант буде глибше розуміти систему вищої освіти, педагогічного процесу, використовувати дослідницькі знання на практиці, мати розвинені комунікативні навички. Однак, організатори магістерської підготовки даного університету не приділяють великої уваги технологічним аспектам управління.

Метою навчання магістерської підготовки майбутніх керівників навчальних закладів університету 
штату Вашингтон є: підготовка працівників сфери освіти до лідерства в школі; проведення систематичного дослідження проблем, політики освіти; експериментування, інновації та розробка моделей удосконалення підготовки співробітників школи; генерація нових ідей з удосконалення освіти; залучення до спільних досліджень та службової діяльності освітньої організації; розвиток систематичних заходів із забезпечення відповідної уваги до освіти студентів різних етнічних груп.

Отже, провідною стратегією магістерської підготовки майбутніх керівників навчальних закладів в університеті штату Вашингтон є підготовка лідерів освіти - дослідників, новаторів, генераторів ідей тощо.

Магістерська підготовка Гарвардського університету забезпечує у магістрантів "більш глибоке усвідомлення того, що таке навчання та викладання; підвищення власного розуміння шкільної культури; оцінювання факторів, які заважають змінам у школах та розробку стратегій подолання цих перешкод; спроможність використання зв'язків та коаліцій; аналіз нових моделей лідерства та колегіальності; спроможність співпраці з батьками та керівниками шкіл; переосмислення ролі, яку можуть відігравати викладачі у реформуванні школи за умов спільної праці".

Таким чином, навчання за магістерською підготовкою майбутніх керівників навчальних закладів в Гарвардському університеті спрямоване на розвиток емоційно-ціннісного та комунікаційного компонентів професійної підготовки при акценті на вивченні системи, якою керують, а саме педагогічному процесі та його особливостях.

В університеті імені Джорджа Мейсона (штат Вірджинія) виділено п’ять загальних цілей магістерської підготовки: служба суспільству; практика мислення; покращення навичок комунікації; розвиток навичок привнесення змін; самооцінювання та планування особистого розвитку. Тобто, за навчальною програмою управління освітою університету імені Джорджа Мейсона головна увага приділяється особистісному розвитку магістранта.

Головною метою навчання за магістерською програмою "Управління освітою" університету штату Джорджія зі спеціалізацією в студентських питаннях (справах) є допомога магістрантам в оволодінні навичками та компетенціями, які необхідні в роботі зі студентами вищих навчальних закладів у таких напрямках, як: розвиток, сприяння міжособистісній співпраці, лідерство в групі, адміністративні принципи роботи. Особлива увага за цією магістерською програмою приділяється розвитку студентів, а саме навчанню та особистому розвитку під час навчання у вищому навчальному закладі. Тобто, університет штату Джорджія пропонує спеціалізовану магістерську програму з управління освітою, яка готує не до викладацької роботи зі студентами вищих навчальних закладів, а працює в секторі надання послуг студентам університету.

Навчання за магістерською програмою "Управління освітою" університету штату Південна Кароліна також передбачає спеціалізацію в управлінні студентськими справами в дворічних, чотирирічних та професійних вищих навчальних закладах. Програма $\epsilon$ збалансованою сучасними теоретичними знаннями, можливостями розвинути критичне усвідомлення студентських справ та застосування результатів досліджень задля поліпшення практики обслуговування студентів. Ті, хто успішно пройдуть програму навчання, зможуть продемонструвати вдосконалені навички комунікації, чітку стратегію визначення та реагування на запити студентів, поглиблене розуміння розмаїття студентських потреб, які потрібно враховувати в процесі розробки програм надання послуг студентам.

На відміну від університету штату Джорджія, університет штату Південна Кароліна спрямовує свою магістерську підготовку на розвиток магістрантами власної стратегії професійного вирішування студентських питань.

Підсумовуючи наведений аналіз цільового компонента навчальних програм, підкреслимо, що загальною метою вивчення дисциплін магістерської підготовки майбутніх керівників навчальних закладів є підготовка освічених, висококваліфікованих спеціалістів у сфері освіти для задоволення регіональних та державних потреб. Крім того, цей аналіз показав, що загальні підходи до формулювання цілей магістерської підготовки не є характерними для університетів США. Тобто, кожний університет самостійно визначає цілі магістерської підготовки за спеціальністю, завдяки чому існує можливість упроваджувати власні оригінальні підходи до навчання.

За дослідженнями С. Бурдіної, відповідно до цілей магістерської програми університет розробляє навчальний план за програмою, де структура та спрямованість блоків навчальних дисциплін віддзеркалюють цілі магістерської підготовки. Оскільки система вищої освіти США $є$ досить різноманітною й вищі навчальні заклади суттєво відрізняються за "місією", структурою, напрямком тощо, це відображається в цілях та змісті магістерських програм [3].

Таким чином, практично в кожному вищому навчальному закладі США є свої особливості в підходах до формулювання цілей і завдань магістерської програми "Управління освітою". Незважаючи на ці особливості формулювання цілей, магістерські програми різних університетів мають багато спільних рис у цільовому компоненті, а саме: розвинуті комунікаційні та лідерські навички, новаторське мислення, уміння застосовувати досягнення дослідників у власній практичній діяльності. 
Американська управлінська культура розглядає управління як спеціалізований вид діяльності, а менеджера - як професіонала, який володіє спеціальними знаннями. В основі американської управлінської культури (як і в європейської) лежить раціоналізм. У ньому чітко виділяється індивідуалізм, опора на власні сили, розрахунковий конкурентний прагматизм. Однак, у 80-ті роки у американців виникли сумніви щодо правильності свого бачення управлінської культури та почали уважно вивчати японську управлінську культуру.

Японська управлінська культура $є$ результатом певного способу життя населення. Аналіз досвіду підготовки керівників навчальних закладів в Японії свідчить, що в цій країні так і не прийшли до ідеї спеціалізованої підготовки управлінських кадрів. Вона формує своїх керівників безпосередньо в закладах освіти, послідовно проводячи їх через ланцюжок посад, починаючи 3 найнижчих. Тобто, підготовка керівника навчального закладу відбувається на робочому місці. Цьому сприяє висока педагогічна культура японців і майже відсутня плинність кадрів.

Європейська модель професійної підготовки майбутніх керівників навчальних закладів має за мету отримання знань на основі практичного досвіду та подальшу самореалізацію людини у закладах підвищення кваліфікації або спеціальної управлінської підготовки. Однак, усі вони містять відповідну управлінську освіту.

Підготовка фахівців у сфері управління здійснюється багатьма європейськими вищими навчальними закладами. Так, наприклад, у Lancaster University iснує широкий вибір програм з менеджменту: МВА програми у режимі full-time, part-time та Global Executive, підприємництво та інновації, людські ресурси, філософія та менеджмент та інші - усього близько 20 програм.

У Голландії поширеним явищем є підготовка керівників освітніх установ на курсах. Існує чимало організацій, що пропонують курси для роботи в сфері освіти. Такі організації можуть входити до університету, педагогічного коледжу, педагогічного інституту чи приватного підприємства. Директор може відвідувати курси чи програми з підготовки менеджерів, які його зацікавили.

Асоціація державного управління освітою в Нідерландах $(V V O)$ пропонує різноманітні короткотривалі, переважно практично спрямовані курси, які охоплюють загальну сферу підготовки керівників школи. Проте, організації, що пропонують курси, не співпрацюють між собою, що спричиняє відсутність єдиних стандартів і якості підготовки.

Підготовка керівників навчальних закладів згідно документів Міністерства освіти Франції передбачає три напрями:

- створення умов для розвитку загальної культури керівника - представника державної влади;

- розвиток компетенцій, специфічних для функцій керівників навчальних закладів відповідно до глобальних суспільних змін;

- сприяння професійній мобільності керівників навчальних закладів.

У Франції підготовка спеціалістів з управління навчальним закладом здійснюється відповідно до кваліфікаційної характеристики, навчальних планів та робочих програм дисциплін. Обсяг навчального часу з дисциплін визначено навчальними планами.

Як зазначає В. Хоменко, програми підготовки магістрів з управління навчальними закладами у Франції включають дисципліни, спрямовані на оволодіння техніками менеджменту, керівництва людськими ресурсами, юридичними аспектами керівництва навчальними закладами, економічно орієнтованими дисциплінами. Так, загальна спрямованість навчальних програм ВНЗ Франції привертає особливу увагу у зв'язку з такими навчальними блоками, як: економічне, фінансове та адміністративне управління освітньою системою; менеджмент послуг, управління якістю у навчальному закладі, аудит, контроль, керівництво проектом, упровадження змін у навчальному закладі, стратегічні підходи до управління, маркетинг та зв'язки з громадськістю, статистика, логістика, інформаційна система на підприємстві, облік і контроль, фінансовий менеджмент, бухгалтерський облік та управління бюджетними коштами освітньої установи [4].

Отже, велика увага у французьких ВНЗ приділяється опануванню майбутніми керівниками навчальних закладів практично-орієнтованими дисциплінами. Крім того, ці дисципліни мають економічний та юридичний напрямок. Важливим аспектом процесу підготовки є виділення великої кількості кредитів на індивідуальну роботу та підготовку дипломної роботи.

На думку Т. Каткової, німецька модель зорієнтована на розвиток у випускника: пізнавальних $\mathrm{i}$ загальних інтелектуальних здібностей, загальної ерудиції, соціальних та особистісних якостей, пунктуальності, працездатності, ощадливості, акуратності, гнучкості, самостійності, лояльності, почуття обов'язку, врахування інтересів підприємства, а також здібностей до уміння вести переговори, встановлювати контакти, розподіляти завдання, приймати рішення, риторичні навички спілкування тощо [5].

Підготовка майбутніх керівників навчальних закладів у Німеччині відбувається як за вимогами Болонського процесу, так і за допомогою змішаної форми навчання, так званої Blended Learning (інтеграція навчання в групі, самостійне навчання, яке здійснюється як в аудиторіях, так і в режимі он- 
лайн). Навчання передбачає використання електронних засобів, роботу в аудиторіях, різноманітні інтерактивні форми. Це дає змогу широко використовувати електронну пошту, Інтернет-конференції, диспути, обмін досвідом тощо. Таке навчання пропонує ряд функцій для підтримки індивідуального навчання, можливості цифрового надання інформації, матеріалів і он-лайн-ресурсів. Так, в університеті Ольденбург середній термін навчання без відриву від виробництва становить 6 семестрів, 3 відривом від виробництва - 4 семестри. Навчальна програма має в цілому 120 кредитних пунктів, 16 навчальних модулів і завершальний магістерський модуль. Усі модулі незалежні один від одного. Порядок навчання й навчальний матеріал передбачають до 30 годин на тиждень.

Навчальний процес складається 3 восьми обов'язкових базових модулів науково-теоретичної підготовки студентів у сфері менеджменту в освіті. При їх вивченні магістри з управління навчальними закладами здобувають знання зі стратегічного менеджменту, економіки та політики в галузі освіти, проектного менеджменту, контролю, права в освіті, фінансового менеджменту й інвестування, організації та керівництва, освітнього маркетингу, менеджменту вищої школи й наукового менеджменту, менеджменту перепідготовки, навчання на основі новітніх технологій, організації та менеджменту змін, обробки даних, інформації та знань, керівництва та кооперації.

Кожний навчальний модуль в університеті Ольденбург складається з п’яти фаз. Першою фазою є фаза підготовки, яка триває чотири тижні та має гнучкий розподіл часу, що відводиться для одержання навчальної літератури для самостійного вивчення. Для контролю успішності розроблені он-лайн завдання, які необхідно завершити до початку першої фази. Друга фаза - це фаза присутності, що триває два дні та передбачає роботу в рамках майстер-класу, на якому формулюється план роботи, обговорюються завдання й робота над проектом. Найтривалішою є проектна фаза, що складається 3 восьми тижнів і має також гнучкий розподіл часу та передбачає обробку проектного завдання у групі 3 трьох або чотирьох осіб згідно робочого плану. Наприкінці строку виконання проектного завдання результати групи узагальнюються у формі презентації. Четвертою фазою є фаза зустрічі, яка триває два дні. При проходженні модуля група надає проектні результати. Також у цей період встановлюється зворотній зв'язок учасників групи з викладачами і однокурсниками. Студенти подають презентацію, яка являє собою частину іспиту. П'ята фаза складається 3 чотирьох тижнів та передбачає написання письмової роботи за власним проектом та подання результатів його виконання. Вона складається 3 частини, що описує індивідуальний внесок студента, і наукової частини, що описує теоретичний базис проекту [6].

Отже, відмінність навчальної програми полягає в тому, що студенти працюють у групах над конкретними проектами, які виникають у їхній виробничій практиці, застосовують теоретичні знання та перевіряють їх важливість для конкретних дій в освітніх організаціях. Окрім цього, у процесі кооперації з носіями інших знань і досвіду формуються нові знання, що ведуть до цікавих підходів у вирішенні завдань і синергії. Виконання цих проектів разом із професійними знаннями є важливою складовою, яка дозволяє використовувати досвід і практичні навички студента.

В інституті Людвігсбург під час підготовки майбутніх керівників навчальних закладів, крім перерахованих дисциплін, які викладаються в університеті Ольденбург, велика увага приділяється наступним предметам: персональний менеджмент, розвиток особистості та компетенція керівництва, комунікація та кооперація, організаційний менеджмент, освітній менеджмент, високорівневий менеджмент.

Особливе місце у навчанні майбутніх керівників закладів освіти займає коучинг. Коучинг (англ. coaching - навчання, тренування) - це метод сучасного консультування, який сприяє ефективному досягненню клієнтом поставлених цілей, вираженому в конкретних результатах. В університетах Німеччини він давно існує як специфічна форма індивідуального навчання [7].

Радянську управлінську культуру відрізняли висока ефективність і результативність в екстремальних умовах та відносно низька - у спокійних. Це перетворилося на постійний поспіх (особливо в кінці місяця, кварталу, року). Важливим для радянської управлінської культури був пріоритет державних проблем над проблемами кожної окремої особистості, що й призвело до ігнорування інтересів окремої особи. Керівники освітніх установ не здобували спеціальної освіти, а набували базового управлінського досвіду. При цьому радянська управлінська культура була гнучкою, могла швидко пристосуватися до змінених обставин, характеризувалась непередбачуваністю поведінки та діяльності, готовністю піти на нестандартні рішення.

Створення ринкових відносин в Україні зумовило потребу підготовки професіоналів-менеджерів освіти. Сьогодні дана спеціальність належить до найбільш перспективних. В Україні все більше університетів забезпечують магістерську підготовку керівників навчальних закладів. Одним 3 них $\epsilon$ Житомирський державний університет імені Івана Франка. Навчання відбувається впродовж двох років на заочній формі.

Під час навчання студенти оволодівають базовими поняттями з галузі менеджменту, педагогіки, філософії, психології тощо. Провідними дисциплінами під час навчання є: керівник навчального закладу, 
менеджмент організацій, управління розвитком персоналу, інноваційний менеджмент, соціальна та екологічна безпека, техніка управлінської діяльності, освітні технології, управління навчально-виховною діяльністю, управління інформаційним зв'язком, правові аспекти управління навчальним закладом, аудит і оцінювання управлінської діяльності, управління трудовими ресурсами, лідерство в організаціях. Зміст даних дисциплін адаптований до специфіки функціонування навчальних закладів різних типів та форм власності. Також під час навчання студенти проходять управлінську практику у загальноосвітніх навчальних закладах та навчальну і наукову практику на кафедрах університету. Певна кількість навчального навантаження відводиться на написання курсових робіт 3 вивчених предметів. Завершальним етапом навчання є написання та захист магістерського дипломного дослідження.

Також керівників навчальних закладів готує університет менеджменту освіти НАПН України, який $\epsilon$ вищим навчальним закладом IV рівня акредитації, який здійснює освітню діяльність 3 підвищення кваліфікації керівних і педагогічних працівників системи освіти та підготовки й перепідготовки фахівців 3 вищою освітою (з управління персоналом та економіки праці, менеджменту організацій, психології, менеджерів-економістів, керівників підприємства, установи та організації, викладачів вищих навчальних закладів).

Магістерська підготовка здійснюється і в університеті імені М. П. Драгоманова. Метою навчання $\epsilon$ формування знань, необхідних для управління різними типами навчальних закладів у сучасних умовах. В університеті здійснюється практичний підхід до навчання: студент виконує завдання в Інтернеті i отримує за це бали, по сумі яких виставляється залік або екзамен; підсумковий контроль по модулям дисциплін проходить у комп'ютерному класі Національного педагогічного університету імені М. П. Драгоманова; захист магістерської роботи на базі Інституту управління та економіки освіти НПУ імені М. П. Драгоманова. Термін навчання складає 2 роки дистанційної заочної форми навчання. В університеті для спеціальності "Управління навчальним закладом" викладаються наступні дисципліни: освітня політика, техніка управлінської діяльності, управління трудовими ресурсами, управління навчальною та трудовою діяльністю, менеджмент знань, правові аспекти управління навчальним закладом, методологія наукового дослідження, теорія прийняття рішень.

Міжрегіональна академія управління персоналом здійснює підготовку керівників навчальних закладів у магістратурі, яка поєднує в собі специфіку навчання адміністративного менеджменту і психологопедагогічних дисциплін дає право випускникам працювати як у галузі загального менеджменту, так і у галузі освіти - викладання, виховання, соціальної роботи тощо. Навчання триває 2 роки на денній формі навчання і 3 роки - на заочній. Дисципліни, що викладаються в МАУП: керівник навчального закладу, менеджмент організацій, управління розвитком персоналу, інноваційний менеджмент, соціальна та екологічна безпека, техніка управлінської діяльності, освітні технології, управління навчально-виховною діяльністю, управління інформаційним зв'язком, правові аспекти управління навчальним закладом, управління персоналом та інші.

Таблиия 1.1

Зарубіжний та вітчизняний досвід професійної підготовки керівників навчальних закладів

\begin{tabular}{|c|c|c|c|c|c|}
\hline Країна & США & Франція & Німеччина & Великобританія & Україна \\
\hline $\begin{array}{c}\text { Термін } \\
\text { навчання }\end{array}$ & $\begin{array}{c}\text { Від } 10 \text { міс. } \\
\text { до } 2 \text { p. }\end{array}$ & До 2 p. & 6 мiс. & До 2 p. & В середньому 2 р. \\
\hline $\begin{array}{c}\text { Орієнтація } \\
\text { навчання }\end{array}$ & $\begin{array}{c}\text { Високий } \\
\text { рівень } \\
\text { освіти, } \\
\text { підготовка } \\
\text { ефективних } \\
\text { лідерів, } \\
\text { виконавців, } \\
\text { керівників, } \\
\text { новаторів, } \\
\text { науковців у } \\
\text { сфері освіти, } \\
\text { особистісний } \\
\text { розвиток. }\end{array}$ & $\begin{array}{c}\text { Розвиток } \\
\text { загальної } \\
\text { культури } \\
\text { випускника, } \\
\text { розвиток } \\
\text { компетенції, } \\
\text { сприяння } \\
\text { професійної } \\
\text { мобільності } \\
\text { КНЗ, } \\
\text { індивідуальн } \\
\text { е навчання та } \\
\text { розвиток } \\
\text { творчої } \\
\text { активності }\end{array}$ & $\begin{array}{c}\text { Розвиток } \\
\text { пізнавальних } \\
\text { та загальних } \\
\text { інтелектуальн } \\
\text { их } \\
\text { здібностей, } \\
\text { загальної } \\
\text { ерудиції, } \\
\text { соціальних та } \\
\text { особистісних } \\
\text { якостей, } \\
\text { пунктуальнос } \\
\text { ті, } \\
\text { працездатнос } \\
\text { ті, } \\
\text { ощадливості, } \\
\text { акуратності, } \\
\text { гнучкості, } \\
\text { самостійності, } \\
\text { лояльності, }\end{array}$ & $\begin{array}{c}\text { Підготовка } \\
\text { висококваліфікован } \\
\text { ого фахівця у } \\
\text { галузі управління } \\
\text { навчальним } \\
\text { закладом }\end{array}$ & $\begin{array}{c}\text { Підготовка } \\
\text { висококваліфікован } \\
\text { ого керівника } \\
\text { навчального } \\
\text { закладу, } \\
\text { формування } \\
\text { комунікативних } \\
\text { навичок, } \\
\text { здібностей до } \\
\text { прийняття } \\
\text { управлінських } \\
\text { рішень, почуття } \\
\text { обов'язку, } \\
\text { індивідуальне } \\
\text { навчання та } \\
\text { розвиток творчої } \\
\text { активності } \\
\text { особистості. }\end{array}$ \\
\hline
\end{tabular}




\begin{tabular}{|c|c|c|c|c|c|}
\hline & & & $\begin{array}{c}\text { почуття } \\
\text { обов'язку; } \\
\text { формування } \\
\text { здібностей до } \\
\text { уміння вести } \\
\text { переговори, } \\
\text { встановлення } \\
\text { контактів, } \\
\text { розподілення } \\
\text { завдань, } \\
\text { прийняття } \\
\text { рішення, } \\
\text { навичок } \\
\text { спілкування } \\
\text { тощо. } \\
\end{array}$ & & \\
\hline $\begin{array}{c}\text { Дисципліни, } \\
\text { що } \\
\text { викладають } \\
\text { ся }\end{array}$ & $\begin{array}{c}\text { Основи } \\
\text { фінансів, } \\
\text { маркетинг, } \\
\text { менеджмент, } \\
\text { бізнес- } \\
\text { аналітика, } \\
\text { бухгалтерськ } \\
\text { ий облік, } \\
\text { економіка, } \\
\text { інформаційні } \\
\text { технології, } \\
\text { етика, } \\
\text { організаційн } \\
\text { а поведінка } \\
\text { та лідерство, } \\
\text { психологія } \\
\text { управління }\end{array}$ & $\begin{array}{c}\text { Економіка, } \\
\text { фінансове та } \\
\text { адміністратив } \\
\text { не } \\
\text { управління } \\
\text { освітньою } \\
\text { системою; } \\
\text { менеджмент } \\
\text { послуг, } \\
\text { управління } \\
\text { якістю у } \\
\text { навчальному } \\
\text { закладі, } \\
\text { аудит, } \\
\text { контроль, } \\
\text { керівництво } \\
\text { проектом, } \\
\text { упровадженн } \\
\text { я змін у } \\
\text { навчальному } \\
\text { закладі, } \\
\text { стратегічні } \\
\text { підходи до } \\
\text { управління, } \\
\text { маркетинг та } \\
\text { зв’язки з } \\
\text { громадськіст } \\
\text { ю, } \\
\text { статистика, } \\
\text { логістика, } \\
\text { інформаційна } \\
\text { система на } \\
\text { підприємстві, } \\
\text { облік і } \\
\text { контроль, } \\
\text { фінансовий } \\
\text { менеджмент, } \\
\text { бухгалтерськ } \\
\text { ий облік та } \\
\text { управління } \\
\text { бюджетними } \\
\text { коштами } \\
\text { освітньої } \\
\text { установи } \\
\end{array}$ & $\begin{array}{c}\text { Організація } \\
\text { виробництва, } \\
\text { педагогіка, } \\
\text { інформатика, } \\
\text { менеджмент, } \\
\text { економіка та } \\
\text { політика у } \\
\text { сфері освіти, } \\
\text { контроль, } \\
\text { право в } \\
\text { освіті, } \\
\text { інвестування, } \\
\text { організація та } \\
\text { керівництво, } \\
\text { освітній } \\
\text { маркетинг, } \\
\text { менеджмент } \\
\text { вищої школи, } \\
\text { науковий } \\
\text { менеджмент, } \\
\text { розвиток } \\
\text { особистості, } \\
\text { персональний } \\
\text { менеджмент, } \\
\text { комунікація } \\
\text { та } \\
\text { кооперація, } \\
\text { організаційни } \\
\text { й } \\
\text { менеджмент, } \\
\text { високо } \\
\text { керівний } \\
\text { менеджмент. }\end{array}$ & $\begin{array}{c}\text { Управління } \\
\text { людськими } \\
\text { ресурсами, бізнес- } \\
\text { адміністрування, } \\
\text { бухгалтерський } \\
\text { облік, маркетинг, } \\
\text { управління } \\
\text { персоналом. }\end{array}$ & $\begin{array}{c} \\
\text { Керівник } \\
\text { навчального } \\
\text { закладу, } \\
\text { менеджмент } \\
\text { організацій, } \\
\text { управління } \\
\text { розвитком } \\
\text { персоналу, } \\
\text { інноваційний } \\
\text { менеджмент, } \\
\text { соціальна та } \\
\text { екологічна безпека, } \\
\text { техніка } \\
\text { управлінської } \\
\text { діяльності, освітні } \\
\text { технологї, } \\
\text { управління } \\
\text { навчальною та } \\
\text { виховною } \\
\text { діяльністю, } \\
\text { управління } \\
\text { інформаційним } \\
\text { зв'язком, правові } \\
\text { аспекти управління } \\
\text { навчальними } \\
\text { закладами, аудит і } \\
\text { оцінювання } \\
\text { управлінської } \\
\text { діяльності, } \\
\text { управління } \\
\text { трудовими } \\
\text { ресурсами, } \\
\text { лідерство в } \\
\text { організаціях, } \\
\text { педагогіка вищої } \\
\text { школи. }\end{array}$ \\
\hline Навчальна & Більша & 2-3 мic. & Вирішуються & Отримуються & 2 тижні в рік. \\
\hline
\end{tabular}




\begin{tabular}{|c|c|c|c|c|c|}
\hline практика & $\begin{array}{c}\text { частина } \\
\text { навчання } \\
\text { займає } \\
\text { практика. } \\
\text { Отримання } \\
\text { реального } \\
\text { професійног } \\
\text { о навику } \\
\text { роботи. } \\
\end{array}$ & $\begin{array}{c}\text { Вирішуються } \\
\text { реальні } \\
\text { практичні } \\
\text { завдання під } \\
\text { час навчання. }\end{array}$ & $\begin{array}{c}\text { практичні } \\
\text { завдання під } \\
\text { час навчання. }\end{array}$ & $\begin{array}{c}\text { практичні навики } \\
\text { управління під час } \\
\text { проходження } \\
\text { практики }\end{array}$ & $\begin{array}{c}\text { Переважає } \\
\text { теоретичне } \\
\text { навчання. }\end{array}$ \\
\hline $\begin{array}{c}\text { Форми } \\
\text { навчання }\end{array}$ & $\begin{array}{c}\text { Денна, } \\
\text { заочна, } \\
\text { дистанційна }\end{array}$ & $\begin{array}{c}\text { Денна, } \\
\text { заочна, } \\
\text { дистанційна }\end{array}$ & $\begin{array}{c}\text { Денна, } \\
\text { заочна, } \\
\text { дистанційна, } \\
\text { коучинг } \\
\end{array}$ & $\begin{array}{c}\text { Денна, заочна, } \\
\text { дистанційна }\end{array}$ & Денна, заочна. \\
\hline
\end{tabular}

Підготовку керівників навчальних закладів здійснює і українська інженерно-педагогічна академія за рішенням ДАК від 2 березня 2006 року, протокол № 59 про видачу сертифіката на право надання освітніх послуг, пов'язаних з одержанням вищої освіти за фахом 8.18010020 "Управління навчальним закладом". Термін навчання складає 1,5 року. Під час навчання вивчаються наступні дисципліни: правові аспекти управління навчальним закладом, теорія організації, менеджмент організації, керівник навчального закладу, управління навчальною та виховною діяльністю, управління фінансово-економічною діяльністю, управління трудовими ресурсами, управління змістом робіт, управління інформаційним зв'язком, техніка управлінської діяльності, освітні технології, психологія управління, аудит та оцінка управлінської діяльності, соціальна та екологічна безпека діяльності. Після завершення навчання, студент отримує кваліфікацію керівник підприємства, установи та організації (у сфері освіти та виробничого навчання) та матиме право управляти навчальними закладами та підрозділами.

Таким чином, в Україні підготовка керівників навчальних закладів в усіх університетах здійснюється в магістратурі 3 середнім терміном навчання 2 роки за навчальними планами, затвердженими Міністерством освіти і науки України. Лише невеликий відсоток дисциплін у варіативній частині навчального плану можуть обирати університети. Під час підготовки керівників навчальних закладів переважає теоретичне навчання, а практиці відводиться лише 2 тижні на рік. Узагальнений зарубіжний та вітчизняний досвід професійної підготовки керівників навчальних закладів представлено у табл. 1.1.

Як видно з табл. 1.1, у зарубіжних ВНЗ майбутнім керівникам навчальних закладів викладаються такі дисципліни, як менеджмент, теорія і практика управління, педагогіка, психологія, а також цикл дисциплін економічного спрямування. 3'ясовано, що у зарубіжних ВНЗ надається перевага практичному навчанню, що сприяє набуттю практичного досвіду та навичок роботи. Можливість змінювати навчальні плани кожного університету сприяє залученню студентів у відповідності з їхніми запитами та новітніми соціальними вимогами.

Зміст педагогічної підготовки менеджера також має будуватися адекватно його професійній діяльності. Основними чинниками, що визначають професійну спрямованість педагогічної підготовки менеджерів є: зміст фахової діяльності і конкретних дій менеджера; повнота предметної галузі фахової підготовки спеціаліста; предметна структура педагогічних наукових знань; інваріантно-особистісний чинник; диференціація змісту педагогічної підготовки фахівця.

Майбутнім менеджерам необхідно не оглядове ознайомлення з азами педагогіки і психології, а поглиблене вивчення соціальної психології і педагогіки в тісному взаємозв'язку з проблематикою людського капіталу. Система педагогічних понять і знань включає підсистему наукових знань про педагогічні основи мотивації (професійний інтерес); підсистему наукових знань про педагогічні основи управління і взаємодії в колективі; підсистему наукових знань про педагогічний аналіз інформації, іiі оцінку і прийняття рішень; підсистему наукових знань про комунікаційний процес; підсистему наукових знань про розвиток і контроль колективу організації.

Зміст педагогічної підготовки повинен бути спрямований на формування системи узагальнених професійно-педагогічних знань, вироблення професійно-педагогічних умінь та навичок, розвиток логічного і творчого мислення.

Висновки. Проведений аналіз основних напрямів професійної підготовки керівників навчальних закладів у країнах Європи свідчить про іiї широкий і різноплановий характер, що визначається наявністю різноманітних програм навчання та підвищення кваліфікації.

До основних сучасних тенденцій професійної підготовки керівників навчальних закладів в країнах Європейського Союзу та США віднесено: активне запровадження накопичувальної кредитно-модульної системи; посилення децентралізації фінансування післядипломної освіти; вдосконалення законодавчоправової бази; активне використання дистанційного навчання; орієнтацію на підготовку студентів до науково-дослідної роботи, гнучке і варіативне навчання; фундаменталізацію навчання; професійну 
спрямованість змісту навчальних програм; можливість послідовного та паралельного оволодіння декількома спеціальностями; активне впровадження сучасних інформаційно-комунікаційних технологій.

Для поліпшення ситуації, на нашу думку, необхідно, перш за все, робити розподіл підготовки керівників навчальних закладів у залежності вид виду закладу освіти, в якому він працює або збирається працювати. Адже, існує певна специфіка функціонування навчального закладу в залежності від його типу. Вагомого значення набуло б перенесення орієнтації навчання майбутніх керівників навчальних закладів на отримання практичного досвіду, а не лише теоретичних знань. Також необхідно запозичити iз зарубіжного досвіду тривалість практичної підготовки керівників, адже існуючий термін, який відведений на проведення практики занадто малий аби отримати достатні навики управління.

Урахування сучасних світових тенденцій у сфері освіти, зарубіжного досвіду щодо впровадження концепції неперервного навчання є важливим для розбудови національної системи освіти, зокрема і для професійної підготовки керівників навчальних закладів, відповідно до стратегічних напрямів освітньої політики України. Зазначене потребує раціонального поєднання форм, методів і засобів формальної, неформальної й інформальної освіти, реалізації принципів академічної мобільності та можливості безкоштовного отримання певних видів освітніх послуг, а також розробки новітніх методичних засад професійної підготовки керівників навчальних закладів.

\section{СПИСОК ВИКОРИСТАНИХ ДЖЕРЕЛ ТА ЛІТЕРАТУРИ}

1. Редько С. Розвиток особистості студента - майбутнього економіста в процесі професійної підготовки [Електроннй $\quad$ ресурс ] / 1 Седько http://archive.nbuv.gov.ua/portal/soc_gum/npo/2005_2/Redko.pdf.

2. Байбородова С. В. Підготовка керівників освіти у Великій Британії [Електронний ресурс] / С. В. Байбородова. - Режим доступу : http://ru.osvita.ua/school/method/31205/.

3. Бурдіна С. В. Особливості формулювання цілей магістерської підготовки з "Управління освітою" в США [Електронний ресурс] / С. В. Бурдіна - Режим доступу : http://studentam.net.ua/content/view/7555/97/.

4. Хоменко В. В. Використання досвіду підготовки менеджерів освіти Франції у вищих навчальних закладах України / В. В. Хоменко // Наукові праці вищого навчального закладу "Донецький національний технічний університет". Серія : педагогіка, психологія і соціологія, 2012. - №2 (12). - С. 28-35.

5. Каткова Т. І. Компетентний випускник - мета і результат діяльності вищого навчального закладу освіти / Т. І. Каткова // Постметодика. - 2002. - № 2-3. - С. 79-82.

6. Zweite Änderung der Prüfungsordnung für den berufsbegleitenden weiterbildenden [Електронний ресурс] // Masterstudiengang Bildungsmanagement mit dem Abschluss "Master of Business Administration" (MBA) an der Carl von Ossietzky Universität Oldenburg vom 21.10.2011. - Amtliche Mitteilungen / 30. Jahrgang - 5/2011. 329 s. - Режим доступу: http://www.unioldenburg.de/uni/amtliche_mitteilungen/dateien/AM2011-05_07 2Aenderung_PO_Bildungsmanagement_MBA FKI.pdf.

7. Алфімов В. М. Організація навчання керівників освіти у Німеччині / В. М. Алфімов // Духовність особистості : методологія, теорія і практика. - № 2 (71), 2016. - С. 6-15.

\section{REFERENCES (TRANSLATED \& TRANSLITERATED)}

1. Redko S. Rozvytok osobystosti studenta - maibutnioho ekonomista v protsesi profesiinoi pidhotovky [Development of Student's Personality - a Future Economist in Training] [Elektronnyi resurs] / S. Redko. - Rezhym dostupu : http://archive.nbuv.gov.ua/portal/soc_gum/npo/2005_2/Redko.pdf.

2. Baiborodova S. V. Pidhotovka kerivnykiv osvity u Velykii Brytanii [Education Managers Training in the UK] [Elektronnyi resurs] / S. V. Baiborodova- Rezhym dostupu : http://ru.osvita.ua/school/method/31205/.

3. Burdina S. V. Osoblyvosti formuliuvannia tsilei mahisters'koi pidhotovky z "Upravlinnia osvitoiu" v SSHA [Features of the Objectives of Master Students Training in "Education Management" in the United States] [Elektronnyi resurs] / S. V. Burdina - Rezhym dostupu : http://studentam.net.ua/content/view/7555/97/.

4. Khomenko V. V. Vykorystannia dosvidu pidhotovky menedzheriv osvity Frantsii u vyshchykh navchal'nykh zakladakh Ukrainy [The Use of Education Managers Training Experience in France in Higher Educational Institutions of Ukraine] / V. V. Khomenko // Naukovi pratsi vyshchoho navchal'noho zakladu "Donets'kyi natsionalnyi tekhnichnyi universytet". Seriia : pedahohika, psykholohiia i sotsiolohiia [Scientific Works of Higher Educational Establishment "Donetsk National Technical University". Series: Pedagogics, Psychology and Sociology], 2012. - № 2 (12). - S. 28-35.

5. Katkova T. I. Kompetentnyi vypusknyk - meta i rezul'tat diial'nosti vyshchoho navchal'noho zakladu osvity [Competent Graduate Student is the Goal and Result of Higher Education Institutions' Activities] / T. I. Katkova // Postmetodyka [Postmetadata]. - 2002. - № 2-3. - S. 79-82.

6. Zweite Änderung der Prüfungsordnung für den berufsbegleitenden weiterbildenden Masterstudiengang Bildungsmanagement mit dem Abschluss "Master of Business Administration" (MBA) an der Carl von Ossietzky Universität Oldenburg vom 21.10.2011 - Amtliche Mitteilungen [Elektronnyi resurs] / 30. Jahrgang - 5/2011. 329 s. - Rezhym dostupu: http://www.unioldenburg.de/uni/amtliche_mitteilungen/dateien/AM2011-05_07 2Aenderung_PO_Bildungsmanagement_MBA FKI.pdf.

7. Alfimov V. M. Orhanizatsiia navchannia kerivnykiv osvity u Nimechchyni [Organization of Education Managers Training in Germany] / V. M. Alfimov // Dukhovnist' osobystosti : metodolohiia, teoriia i praktyka [Spirituality of a Personality : Methodology, Theory and Practice]. - № 2 (71), 2016. - S. 6-15. 


\section{Кравчук О. С. Отечественный и зарубежный опыт профессиональной подготовки руководителей учебных заведений.}

В статье представлено отечественный и зарубежный опыт профессиональной подготовки руководителей учебных заведений, рассмотрено её формы и методы, рассмотрено подготовку руководителей в университетах Америки, Европьl, Японии и Украинь, проведен анализ исследований и публикаций данного вопроса, выделено основные характеристики содержания подготовки руководителей сферы образования.

Ключевые слова: руководитель, руководитель учебного заведения, магистратура, магистерская подготовки, образовательные учреждения, учебный прочесс.

\section{Kravchuk O. S. Domestic and Foreign Experience of Professional Training of Heads of Educational Institutions.}

Nowadays the urgent task of the professional formation is the kind of training the result of which means the ability to adapt to changes in life easily; to improve one's professional competence, which can be provided using both foreign and domestic experience. Comparing foreign and domestic experience of managerial culture formation it is evident that they have some differences. The American model is focused on social, demographic and structural factors that are changing the world, service to society and personal development of a student. The preparation of future school principals are more focused on practical experience than theoretical knowledge.

The main difference between the American model and the Ukrainian one is that each university defines the graduate education goals and develops curricula independently. The Japanese model of school principals preparation is completely different from all the others. Thus, to obtain the position of the head of the educational institution one must serve in all positions, starting with the lowest one and have a diploma with the highest number of credits (points). School principals preparation should take place while getting the profession of a teacher. The European model, as well as the Americam one is, aimed at students obtaining practical experience.

School principals preparation is provided in accordance with the qualification characteristics, curricula and working programs of disciplines, like in Ukraine. There are also training courses at universities, colleges, institutes, enterprises. To gain the appropriate level of business relations and business communication, executives, managers and principals in Ukraine must learn all the time, both theoretically and in practically.

Key words: manager, manager of an educational institution, master's degree, master's training, educational institutions, educational process. 